\title{
LUCHAS Y COMPETENCIAS DIGITALES DE LOS PROFESORES DE INGLÉS DURANTE LA PANDEMIA DE COVID-19

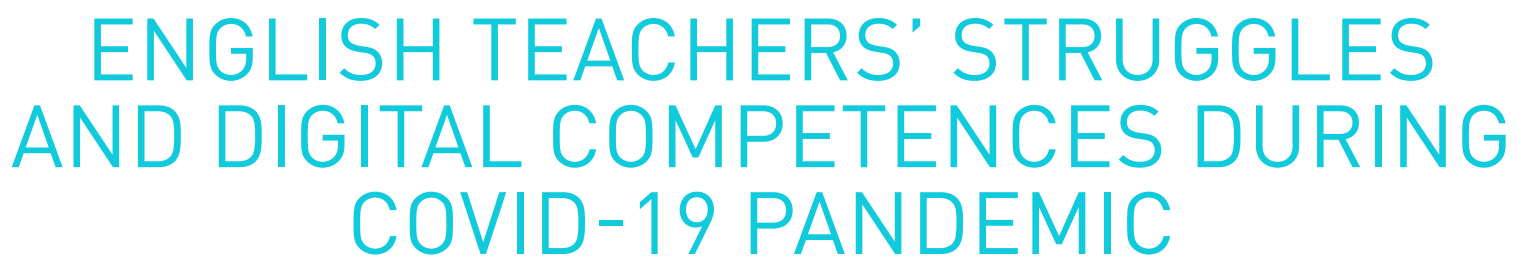

Camila Morales Triviño ${ }^{1}$

Juliana Vargas Rodríguez ${ }^{2}$

Astrid Ramírez Valencia ${ }^{3}$

\section{RESUMEN}

Las competencias digitales son el conjunto de elementos centrados en la gestión y creación de entornos educativos con fines específicos de enseñanza y aprendizaje. Sin embargo, la pandemia trajo consigo un cambio repentino que no garantiza que los profesores de inglés tengan estas competencias para adaptarse plenamente

$1 \quad$ Estudiante en formación del programa de Licenciatura en Educación Básica con Énfasis en Inglés. Estudiante Investigador, Universidad Distrital FJDC. Correo institucional: mcmoralest@correo.udistrital.edu.co ORCID: https:// orcid.org/0000-0001-9040-572X

2 Estudiante en formación del programa de Licenciatura en Educación Básica con Énfasis en Inglés. Estudiante Investigador y docente de inglés, Universidad Distrital FJDC. Correo institucional: jvvargasr@correo.udistrital.edu.co ORCID: https://orcid.org/0000-0001-7484-0385

$3 \quad$ Docente Universidad Distrital Francisco José de Caldas Bogotá, Colombia, Ph.D. en Lenguaje y cultura, formadora de profesores de inglés durante más de 25 años. Investigadora y maestra en la Universidad Distrital Francisco José de Caldas. correo aramirezv@udistrital.edu.co ORCID: https://orcid.org/0000-0002-3025-5982 a los entornos educativos digitales. El objetivo es reflexionar sobre las limitaciones y aptitudes que los profesores muestran en la gestión de estos entornos digitales en la enseñanza del inglés mediante el análisis de entrevistas, cuestionarios y observaciones. Para ello se analizarán: a) las limitaciones que los docentes encuentran en la gestión de los recursos digitales, b) los proyectos educativos para formar a los docentes en las TIC, y c) las competencias digitales. En conclusión, para que los docentes adquieran y refuercen las competencias digitales, antes de arriesgarse a hacer un mal uso de las TIC, deben reconocer los recursos de los que disponen para capacitarse y utilizar la tecnología de manera adecuada para fines enteramente educativos.

PALABRAS CLAVE: Competencia digital, TIC, aprendizaje remoto 


\section{ABSTRACT}

Digital competencies are the group of elements focused on the management and creation of educational environments with specific purposes of teaching and learning. However, the pandemic brought with it a sudden change that does not ensure whether English teachers have these skills to adapt to digital educational environments fully. The lens reflects on the limitations and aptitudes that the professors must-have in the gesture of these digital environments in the median study of the mediocre analysis of interviews, questionnaires, and observations. For this, we analyze the following aspects: a) the limitations that teachers find in the management of digital resources, b) teachers training in ICTs and c) digital competencies. To conclude, for teachers to acquire and reinforce digital skills, before risking misuse ICTs, they must recognize the resources they have to train and use technology appropriately for entirely educational purposes.

KEYWORDS: Digital competence, ICT, remote learning

\section{INTRODUCTION}

The current situation in the world has forced education to adapt to technology, looking for alternative ways of interaction, teaching, and learning. Teachers have had to migrate from face-to-face environments to digital spaces, and in turn, be committed to training and acquiring skills that allow them to function better through various teaching platforms and achieve success in this adaptation and migration processes. But this means English teachers have to overcome the barriers of adaptation to technology, recognize the existence of training tools in the use of ICT for teaching and learning, and finally to develop and reinforce digital competencies that allow the management of digital educational environments.
English teachers do not feel capable enough to explore technology deeply beyond grammar exercises. The previous idea relates to the findings of (García \& Rey, 2013) who state that "the implementation of technology is carried out more in terms of reinforcement and consolidation of structures worked in class rather than in enhancing the process of learning and teaching a language in a more meaningful way.". Then they limit their opportunities and increase the deficiencies in competencies related to digital academic tools. But the migration to digital learning environments has made technology be the primary tool to carry on interaction, teaching, and learning processes.

Additionally, to develop and reinforce digital competencies that allow managing digital educational settings, it is necessary to recognize that teachers have access to training tools in the use of ICT for teaching and learning. Valencia, M et al. (2016) establish that skills in the design of educational scenarios supported by ICTs lead to the planning and organization of elements that allow the construction of meaningful learning but they must be prepared. This, supported by The National Ministry of Education, as well as the UNESCO, which from educational platforms enable the reinforcement of skills in managing technologies for teaching and learning proposals, and in turn, allow education to move hand in hand with the digital world.

Then, in this document, we will approach some concepts related to digital competencies and struggles in the integration of technology in education. The previous, to identify the digital competences that English teachers have in the management of ICTs for remote learning. As well as To analyze what type of resources teachers use and how these resources provide practices and processes that will contribute to strengthen understanding. In consequence, teachers require a guide for the development, management, and application of their teaching and learning 
competencies facing real challenges in the use of technology. The previous statements lead us to the following question: What digital competences do English teachers emphasize on when managing ICTs for remote learning?

\section{LITERATURE REVIEW}

This study was designed based on two concepts: digital competencies and ICT. In this section of the paper, we will go through a reflection in which the thoughts of digital competences and ICT are part of teachers' struggles in the adaptation process to digital educational environments, and we will examine those concepts.

\section{DIGITAL COMPETENCIES}

The digital age has brought significant changes regarding education and the market; therefore, new competencies have emerged that are necessary to face the demands of today's society. This section shows the teaching competences in the digital age, intending to characterize the teachers training profile in the English area.

Competencies are described as "a molar construct referring to a set of knowledge and skills so that people can carry out any activity" (Prendes, Guiereez, \& Martínez, 2018). This concept relates to the problem-solving ability, and the application of information depending on the context and problem linked needs. Therefore, teachers must comprehend not only the handling of technology; they must also be aware of its application, benefits, risks, and management. This statement includes the selection of materials used in the classroom and their purpose; that is, what teachers want to achieve with the tools integrated in the lessons.

On the other hand, UNESCO traces digital competences for teachers from a pedagogical perspective, ascertaining their meaning as "those planning and organization skills of elements that allow the construction of educational scenarios supported by ICT for meaningful learning and integral formation of the student" (2016). Some competencies described by (Viñas) for teachers are: knowing how to search on the Internet, manage information, create multimedia lessons, connect virtually, participate in social networks, understand copyright, create and manage remote learning, and working with tablets. All the authors agree to present the competences as skills that are acquirable and fulfilled to improve teaching practices.

To contribute to the development of these competencies in 2017, the Google platform in collaboration with the UGR (University of Granada), offered a program for the training and acquisition of technological knowledge and tools called 'Digital garage,' the program supports English teachers during their adaptation process to the current work environment. This project illustrates the keys, techniques, standards, and tools to operate systems updated, problemsolving and security, proper ICT management, content creation, and communication management, allowing the development of skills in new generations of educators.

Teachers must include technology in the educational system as a tool to improve their efficiency and the results in the teaching process. However, the process of inclusion should consider more than the integration of new devices to the classroom. According to UNESCO, "the integration of technology in education should be considered in the most general field of institutional innovation, the question does not occupy in favor or against ICT's for what will happen with them in education" (2016). Our education seeks to satisfy the needs and desires of today's society, the market, and the educational policies that guide teaching innovation in the classroom. However, many pre-service teachers have difficulties responding to these demands. For this reason, these teachers must receive 
instruction on how to integrate technology into English classes.

\section{ICT (INFORMATION AND COMMUNICATION TECHNOLOGIES)}

The term Information and communication technologies (ICT) refers to the confluence of the different technological tools that allow to produce, receive, store, share, access, and process information, which is part of different codes (images, texts, sounds, among others). "The most representative element in recent years is the computer and, more recently, the use of portable technologies such as the mobile phone (smartphone), among others." (Hernández, 2017). ICTs are a variety of tools that have transformed how we access information. In today's society, where technology plays a fundamental role in every aspect of life, it is necessary to consider the new conditions established by the global health crisis, where ICTs have become even more relevant in the field of education.

The implementation and practice of ICT can promote change and improvement in all aspects of the syllabus and the teaching methods, which, in turn, generates a difference in digital learning environments. The previous can be summarized in a series of benefits for the teaching field since apart from allowing a better adaptation of the English teacher in the handling of technologies, it also allows the teaching and learning processes to be more interactive, adaptable, and innovative. Authors such as Hernandez (2017), Gafiyatova et al. (2019), Candel \& Agustín (2020), among others, have described the advantages and disadvantages related to the use of ICT in education. As a starting point for the development of significant activities and materials, "technology has become an engine for opportunities, allowing the potential to innovate in education, where the results generated by this scientific development should seek to address such social-educational issues as are useful for development" (p. 340).
Other advantages described in the literature are: Easy access to a wide range of information sources; synchronous communication channels (web conferencing) and asynchronous (online discussion forums); storage and digitalization of all information; increasement of interest and attention; improvement of critical thinking and participation.

Apart from the advantages and disadvantages of the use of ICT in education, it is essential to highlight the teachers' role as mediators in the interrelationship of technology and culture. As described by Aguilar (2019), to achieve an exact process, one must employ cognitive skills, such as analysis, synthesis, generalization, deduction, abstraction, among others. It is here that the teacher intervenes as an intermediary for the development of capacities, the appropriation of knowledge, and their creation and distribution. Technology does not only refer to the management of the devices and platforms; it also includes experimentation, testing, dissemination, implementation, and appropriation processes. And each of the previous represents a constant improvement where each process involves a series of transformative and innovative teaching conceptions to achieve aptitudes and attitudes towards research, science, and technology.

On the other hand, some disadvantages hinder the implementation of ICTs in education. Many of these disadvantages have been evident during the isolation caused by the pandemic and have made it difficult for educators to adapt to digital environments. Some of the most important presented by Quiroga et al. (2019) and Klement (2017) et al. are: Technical problems: (incompatibilities between systems, low internet speed, etc.); ethical issues (access to privacy,, plagiarism and lack of integrity in information, piracy, and "cyberbullying,"); economic barriers: (networks and equipment); and attitudinal barriers such as resistance to change by teachers and more traditionalist citizens in society. 
Education provides elements of innovation; therefore, professionals must apply the appropriate methodologies for the solution of new problems that may arise in the workplace. Also, the dynamics of working life present challenges that provide opportunities to increase knowledge and improve what exists. From the above, we can affirm that the use of ICT in educational processes has two fundamental characteristics: First, it is not isolated because it depends on external factors (devices, accessibility, competencies) and internal (beliefs, experiences, emotions). Second, it consists not only of teaching through technology, but of learning to develop and generate social, scientific, and technological benefits to society.

\section{REMOTE LEARNING}

Teachers were challenged by the COVID-19 pandemic in their ability to adapt to technologymediated learning environments. According to (Reyes, C; Talbot, C; Quezada, K. (2020), "The twenty-first century has brought a growth in information and digital knowledge that is difficult to keep up with, together with new demands and complexity in the workplace." From this need, arises the remote learning as a teaching and learning process performed at a distance in which students and teachers work together synchronously and asynchronously, suitable and convenient for times of lockdowns and social distancing due to COVID 19 pandemic. (Ali, W, 2020)

Within this, the teachers fulfill the role of "models for their colleagues, exploring and identifying new technological tools for learning." (Morgan.H 2020). However, one of its limitations within the construction of this remote model is to find equal access to technology to satisfy the needs of all students. Or, teachers may have access to technologies, but the use of them to carry out remote learning processes is regular. The domain that teachers have over digital resources varies, and it is necessary to take into account the required competencies and the requirements of ICT for this to be carried out successfully. That in accordance with Allen, J; Rowan, L; Singh, P. (2020), it is necessary to take into account that the instant change to online teaching and learning environments has led to significantly intensified workloads for teachers as they work to not only create teaching content and materials into the online space, but also become sufficiently adept in navigating the platforms.

Taking into account the above, in reference to remote learning, Reyes et al. (2020) establishes that it is necessary for teachers training processes " to have their "instructional digital technology toolbox' full of resources to work with teacher candidates so they may better prepare to teach students equitably, and with inclusivity, in primary, secondary and other school education settings." Morgan, H (2020) suggest recommendations such as the implementation of methods "to ensure equity, communicating expectations clearly, and providing studentcentered learning to use free online resources" to face premature changes that pandemic brought such working face to face to remote teaching and learning environments.

\section{METHODOLOGY}

The purpose of this study is to gather information about struggles and competencies towards the use of technology in teaching and learning English. And also, to analyze and recognize the competencies that teachers should develop for managing technology for educational purposes.

This research is mixed, covering elements such as the analysis of specific digital competencies that the Ministry of Education proposed, as well as reflections on the experience and effectiveness of English teachers in the use of technologies for teaching and learning. 
This study takes place in different institutions located in Bogotá, and the population of the study is the English teachers from different communities. Due to the pandemic, the study moves through remote groups of English teachers whose age is between 20 and 46 years old. As well as its sample is random due to all interviewed subjects having an equal opportunity to participate in the final results of this reflective and investigative project.

As data collection instruments we employed the surveys, interviews and observations, considered as appropriate instruments to collect the expected information due to people being able to share their struggles. Also, this is for analyzing the digital competences that English teachers have in the management of ICTs for remote learning. These instruments consist of a series of questions on the following topics:

Q The implementation of technologies.

$\otimes \quad I C T s$ in English language teaching.

$\quad$ Native and digital immigrant teachers.

$\otimes \quad$ Teachers' training in ICT.

As well as, it contains the competencies proposed by the Colombian National Education Ministry.

$\otimes \quad$ Useful programs to create remote learning environments.

\ Virtual platforms are applied in the classroom.

$\nabla \quad$ The tools that are necessary for the development of digital material.

$\otimes \quad$ Teachers support in ICT training programs.

Q Technological skills that English teachers may have in the XXI century

\section{RESULTS AND DISCUSSION}

\section{INTERVIEWS:}

From the results obtained from the interviews with English teachers, it is possible to say that the participants take into account a central element to establish the concept of digital competence. In the first place, we find the handling of virtual platforms as a determining factor to describe the digital competence of teachers; in this case, $90 \%$ of the interviewed people included the handling of tools and digital platforms as a fundamental aspect to measure their adaptation. This description differs from those proposed by UNESCO, whose definition of digital competence includes nine items that cover a variety of characteristics, including the management of information, copyright, and materials design, among others.

Their conception of digital competence is directly related to the knowledge and handling of the different platforms. This idea leads to thinking that English teachers have given special importance to their professional development in this area; some of them stated that they have taken courses and learned different skills on their own or with the help of other teachers:

"When we made meetings with other teachers, we shared what we have learned and we all included new things in the classes. However, the majority of us had to learn by ourselves. It was very difficult at the beginning, but it was an improvement because I feel more confident now than when we started online classes"

According to the above, there is a need to train English teachers in digital skills and their relationship to learning to improve the experience of teachers and students in the English classes. 
Next, we present two specific questions related to the use of technologies in the classroom. The first part depicts the answers to the question: What limitations did you find in the management of digital resources for teaching?

The first element is related to access to technology and especially to the Internet; the total number of those interviewed referred to the lack of connectivity, the speed, and stability of the Internet, among others. In spite of being an external factor to teachers, it has a great impact on the development of their classes and represents a latent problem for them and their students. The second element highly mentioned was the lack of optimal equipment and devices for teaching and receiving classes. Almost $80 \%$ of the teachers considered their equipment and those of the students not suitable for remote learning environments and had experienced such as the impossibility of attending a class, of making a video or a presentation, and the difficulties of running a remote class. Other difficulties related to the platforms speak of the restrictions in the access to different quality tools, which made the creation and application of new strategies and materials difficult; on the other hand, the lack of experience and knowledge in the handling of the virtual platforms made the teaching work more difficult and doubled the time and effort required to develop their classes.

Finally, we found difficulties at the pedagogical and class management level. Some teachers reported low student participation who seem unmotivated and disconnected from learning; furthermore, few opportunities for group work and interaction between students were evident either due to lack of experience in managing the group or ignorance of the options offered by virtuality. Similarly, communication between students and teachers has been limited outside virtual meetings, which affects interpersonal relationships and the transmission of information, instructions, and even clarifications and corrections of activities.

In the data collected, a vague and superficial approach to the available means is described; but the emphasis is placed on the lack of practical applications that allow teachers to implement and work with virtual content to complement their classes. Thus, it is important that teacher training considers and integrates new technological practices according to the approaches made by UNESCO (2016) so that ICTs have a relevant influence on the development of English classes.

The second question revolves around the professional development of teachers and the competencies they have acquired throughout this experience. This section presents the answers to the question: What digital competencies have you acquired in the course of the pandemic?

As mentioned above, the English teachers interviewed focused on the use of digital platforms. A summary of the information obtained is presented below: 


\begin{tabular}{|c|c|c|}
\hline Categories & Platforms & Percentages \\
\hline \multirow{4}{*}{ Content creation } & PowToon & $20 \%$ \\
\cline { 2 - 3 } & Genially & $12 \%$ \\
\cline { 2 - 3 } & Scratch & $4 \%$ \\
\cline { 2 - 3 } & Nearpod & $5 \%$ \\
\cline { 2 - 3 } & Hot potatoes & $15 \%$ \\
\hline \multirow{4}{*}{ Evaluation } & Kahoot & $2 \%$ \\
\cline { 2 - 3 } & Quizlet & $6 \%$ \\
\hline \multirow{2}{*}{ Communication } & Zoom & $6 \%$ \\
\cline { 2 - 3 } & Google Meet & $12 \%$ \\
\cline { 2 - 3 } & Microsoft Teams & $6 \%$ \\
\hline Presentations & Microsoft Office & $3 \%$ \\
\hline \multirow{3}{*}{ Course Design } & Moodle & $6 \%$ \\
\cline { 2 - 3 } & Classroom & $3 \%$ \\
\hline
\end{tabular}

These tools integrate elements of design, animation, programming, information search, content organization, gamification, and interactivity. These platforms enrich online classes and are a means for the development of digital skills and knowledge for both teachers and students.

Finally, the teachers described the use of new resources as an important part of innovation within the classrooms; they expressed the discovery of new sources of information (tutorials, educational videos, educational websites, online communities, etc.) that contributed to their practice and professional development. Concerning the management and organization of classes and content, teachers said they had acquired new skills in the communication of instructions and information. They also found new ways to present the contents of the class (design, synthesis, search, analysis); teachers developed different strategies to encourage participation and applied new knowledge for the creation and organization of courses that are more flexible and aimed at the needs of students.

\section{SURVEYS:}

\section{Teacher training}

With respect to teacher preparation, most of the interviewed teachers stated that they have not received sufficient training regarding the use of technological resources. Valencia, $M$ et al. (2016) consider that the integration of ICTs into education requires a complete exercise of appropriation for the enrichment and transformation of educational practices, aimed at encouraging the construction of knowledge. But, most of the teachers expressed discomfort towards the training they received by the use of Information and Communication Technologies.

The highest percentage in graph number one represents a negative response to teacher preparation. Similarly, the smallest percentages represent teachers' statements and their dissatisfaction with respect to ICT teacher training, they went through processes but can be considered inefficient or did not reach the expected goals. This represents great affections in teaching practice, since Jiménez, 
M., \& Abanades, M. (2016), consider that when digital immigrant teachers do not perceive the development of their digital competence, they may experience greater anxiety when facing those teaching and learning situations. The use of ICT places them at a disadvantage compared to their students.

However, this is only the responsibility of the teacher. English teachers need to recognize and participate in the training opportunities that are offered to them. Several said they were knowledgeable about certain ICT training groups, but they did not dare to participate because they felt satisfied with the knowledge they already have regarding the management of digital resources. Which is important to clarify. Well, the management of these resources does not imply that all the rules are being met and that the teaching process is being carried out correctly.

\section{DIGITAL COMPETENCES}

There is great variability and some deficiencies with regard to the development and application of digital skills within the educational framework. The MEN raises a series of competences that all teachers must have in relation to the management of digital educational environments. Within this, it is shown that teachers may have several of the requirements established by the MEN as well as ignore half of them.

The characteristic that more percentage shows is the development of learning activities using applications, content, computer tools, and audiovisual media. Although the success of this result also depends on the purpose that the teachers are giving to the resources mentioned there. It is common that teachers make use of technology for reinforcement and consolidation of topics worked in class rather than in enhancing language learning and teaching processes in a more meaningful way.(García \& Rey, 2013) Then, there is ambiguity between the application of these aids, if they are directed only to the creation of material, to teaching directly or only to give feedback.

In addition, the MEN emphasizes on the characteristics, uses, and opportunities that technological tools and audiovisual media offer to teachers in educational processes. The purpose is to use technology tools to help students to build meaningful learning and develop critical thinking. Many teachers recognize the benefits that digital resources bring to classes but they do not take the risk. It is useless to know the scopes that technology offers if teachers are not sufficiently prepared to implement it with educational purposes specifically, in such a way that the reinforcement of digital competences is regular as it is evidenced in the figure 2 .

Elements of intellectual property are evidently taken into account but it is useless, due to teachers show a lack of use of specialized technological tools to design remote learning environments. There is no correlation between the group of digital competencies, for instance, teachers are not sufficiently prepared to carry out teaching and learning processes remotely. Taking into account Santos, L; Kadri, M; Salles El; Gamero, R; Gimenez, T. (2018), teachers have to 'rethink the language classroom beyond pedagogical practicalities, such as ways to better integrate digital technology in the existing language education curricula' to generate more opportunities to improve their teaching, learning and researching experiences. They use technology but not in an appropriate way, not with teaching proposals specifically.

\section{OBSERVATIONS:}

In terms of observations, we found that teachers present three problems when using technology during their classes.

The most common situation is the limitation of teachers to use the tools in the classroom. Many of them focus on presenting the contents through 
videos, slides, games, among others. Another frequent use of ICTs in English classes is for evaluation through games and questionnaires. However, most do not make use of interactive platforms that promote student participation. In general terms, teachers were looking for a replacement for the common elements of classes in remote teaching.

Another difficulty we encountered was the organization and integration of technology into classroom activities. In many cases, students had to enter other pages, review videos, write texts, etc. However, many times teachers did not know how to make these transitions, and students lost track of the class, thus hindering their development.

On the other hand, we observed difficulties external to the teachers' management, such as connectivity problems and devices. In other cases, it was evident the lack of skills of the students in the handling of the virtual tools. of motivation, desertion, and delay in the delivery of work. All this, although far from technology, has a relevant impact on remote learning.

\section{CONCLUSIONS}

The current situation has offered teachers to adapt to new work spaces but they are not sufficiently trained in ICT as well as in the development of digital skills. Most teachers defend themselves in the control of a technological resource, but there is a high level of fear regarding the handling of specialized digital platforms for the creation, publication of materials and, in the same way, carry out teaching processes instead of feedback. Teachers have various limitations and still face this adaptation process. As various authors mentioned, it is necessary for teachers to rethink their role and the use they are making of technology to carry out their practice.

Similarly, it should be clarified that this process of adaptation to remote teaching spaces takes a short time, but this does not imply that teachers are left behind. On the contrary, they must find a way to go hand in hand with the changes to achieve successful learning and teaching processes. Remote learning should be seen as an opportunity to innovate within their own practices, and develop skills that allow them to improve their work, as well as contribute to their students.

\section{BIBLIOGRAPHIC REFERENCES}

Ali, W. (2020) Online and Remote Learning in Higher Education Institutes: A Necessity in light of COVID-19 Pandemic. Canadian Center of Science and Education,10 (3), 16-25.

Aguilar, M. J. G. (2019). Wanda C. Rodríguez Arocho. Tecnologías de la información y la comunicación: nuevas configuraciones mentales y sus implicaciones para la educación. [Information and communication technologies: new mental configurations and their implications for education]. Revista de Psicología, 27 (1), 1-12.

Allen, J; Rowan, L; Singh, P. (2020) Teaching and teacher education in the time of COVID-19, Asia-Pacific Journal of Teacher Education, 48:3, 233-236.

Gafiyatova, E. V., Gaynutdinova, D. Z., Galiakhmetova, A. T., \& Levchenko, V. (2019). The integration of pedagogical technologies as a condition for improving the quality of education. $3 \mathrm{C}$ TIC. Cuadernos de desarrollo aplicados a las TIC, 126-139.

García, M; Rey, L. (2013). Teachers' Beliefs and the Integration of Technology in the EFL Class. HOW. 51-72. 
Google, (2017). Formación gratuita en competencias digitales.[Free training in digital skills.] Retrieved from: https:// www.google.es/landing/activate/home/

Hernandez, R. M. (2017). Impact of ICT on Education: ChallengesandPerspectives. Journal of Educational PsychologyPropositos y Representaciones, 5(1), 337-347.

Jiménez Bernal, M; Abanades Sánchez, M. (2016). La competencia digital en los docentes del siglo XXI: Hábitos de uso y autopercepción. Retrieved from: https:// journals.eagora.org/revEDUTECH/ article/view/151/920

Klement, M., Dostál, J., Bártek, K., \& Gregar, J. (2017). Perception and Possibilities of ICT Tools in Education from the Teachers' Perspective. Palacký University Olomouc.

MEN (2013). Competencias TIC Para EI Desarrollo Profesional Docente. [ICT Competencies For The Professional Development Of Teachers]. Bogotá, Colombia. Retrieved from: https:// www.mineducacion.gov.co/1759/ articles-339097 archivo pdf competencias tic.pdf

Morgan, H. (2020) Best Practices for Implementing Remote Learning during a Pandemic. The Clearing House: A Journal of Educational Strategies, Issues and Ideas, 93:3, 135-141.

Quiroga, L; Jaramillo, S; Vanegas, O. (2019). Ventajas y desventajas de las TIC en la educación "Desde la primera infancia hasta la educación superior" [Advantages and disadvantages of ICT in the education "From early childhood to higher education"]. Revista Educación y Pensamiento, 26(26), 77-85.

Reyes, C; Talbot, C; Quezada, K. (2020). From bricks and mortar to remote teaching: a teacher education programme's response to COVID-19. Journal of Education for Teaching.

Santos, L; Kadri, M; Salles El; Gamero, R; Gimenez, T. (2018).Teaching English as an additional language for social participation: digital technology in an immersion programme. 18 (1), 2955. Revista Brasileira de Linguística Aplicada. Faculdade de Letras Universidade Federal de Minas Gerais.

Valencia, M; Serna, A; Ochoa, S; Caicedo, A;Montes, J; Cháves, J. (2016). Competencias y Estándares TIC desde la dimensión pedagógica:Una perspectiva desde los niveles de apropiación de las TIC en la práctica educativa docente. [ICT competences and standards from the pedagogical dimension: A perspective from the levels of appropriation of ICT in the educational teaching practice]. Pontificia Universidad Javeriana. Retrieved from: http://www.unesco.org/new/fileadmin/ MULTIMEDIA/FIELD/Santiago/pdf/ Competencias-estandares-TIC.pdf

Viñas, M. Competencias digitales y herramientas esenciales para transformar las clases y avanzar profesionalmente. [Digital skills and essential tools to transform classes and advance professionally]. Retrieved from: https://cursoticeducadores.com/ ebook- competencias-digitales-blog. pdf?inf contact key=

7b2df2296a82f5910679963ad6c

951b5d868cfd58775b52a222f7

$\underline{b d 710 f f 40 c c}$ 